\title{
Moral analysis of an economic collapse - an exercise in practical ethics
}

\author{
Vilhjálmur Árnason
}

In this paper, I discuss how a Working group on ethics dealt with the question whether the collapse of the Icelandic banks and related financial setbacks can to some extent be explained by morality and work practice. I describe how the Working group delineated its subject matter by evaluating practice in the financial sector, the administration, the political sector and the social or cultural sector. I demonstrate the approach used by the Working group by discussing some important examples which throw light on some aspects of its manifold analyses. The examples show how different aspects of morality are of importance in an analysis of the events that took place.

Keywords: banking, professionalism, politics, responsibility, social discourse

\section{Introduction}

In the wake of the collapse of the three leading Icelandic banks in October 2008, the Icelandic parliament passed a law regarding a Special Investigation Commission (SIC) which had the task of finding out the truth about the events that led to the crisis. ${ }^{1}$ The law contains an article on a Working Group on Ethics (WGE): «In relation to the work of the special investigation commission, there shall be an inquiry of whether the collapse of the banks and related financial setbacks can to some extent be explained by morality and work practices.» ${ }^{2}$ It is stated in the law that the members should have education in philosophy, history, sociology, political science, media or other comparable disciplines. The members of the WGE were appointed by the governing committee of the parliament and it consisted of two philosophers 
and a historian. ${ }^{3}$ The WGE delivered its report to the parliament April 12, 2010, as part of the final report of the SIC. ${ }^{4}$

In the letter of ordinance from the president of the Icelandic parliament to the members of the WGE, dated January 14, 2009, it is stated that the inquiry is not to be limited to morality and work practice in the financial sector; other sectors of society may come under scrutiny as well. In light of this, the WGE decided to assess morality and work practice in three main sectors or social spheres: the business and financial sector, the administrative and political sector and in the social or cultural sector. Obviously, this entailed the risk of impairing precision but the members of WGE thought that the approach as a whole would suffer from a lack of precision if this was not done. As our analysis developed, it became clear that actions in the financial and administrative sectors could not be explained without relating them to the wider social context.

Analyses in applied ethics are often prone to criticism by focusing too narrowly on particular ethical questions at the neglect of the larger social implications. ${ }^{5}$ The WGE tried to avoid this without losing sight of particular events in the financial and administrative sectors. An obvious way to let the general and the particular interact properly in the analysis is to work from examples which demonstrate relevant features in a particular context that also reveal structural processes and ideas. As will become clear in the following, the particular events are the focus of the analysis. This comes from the nature of the work which was mainly based on various types of data from the banks, oral reports given by individuals in formal hearings during the process and material from media covering the events in the years before the banking crisis.

The WGE took as its normative guidelines the intrinsic features of morality as well as ideas of good work practice in the sectors under scrutiny. Morality is commonly divided into a four major elements: Moral values, virtues, rules, and obligations. Each of them requires contextual analysis, as parts of an ethos, be it financial, political or social, which gives them concrete characteristics and direction. When the basic moral features are contextually analyzed they become intertwined with good work practice. This becomes a basis for a critical evaluation, an internal criticism of actual work practice.

In the following discussion, I will consider a few examples of how the different elements of morality were of relevance in the task of explaining the actions and interpreting the culture which facilitated the fall of the Icelandic banks. The following issues will be discussed: (i) how virtues and vices enter into the analysis of morality in the banking sector and how they colored the social discourse; (ii) how the analysis shows a breach of good work practice in the administrative sector where moral rules for public service were violated; (iii) how the analysis demonstrates that politicians and other guardians 
of the public interest failed to respect their primary obligations; (iv) how the prominent moral values of the ruling ideology provided the soil for various forms of conduct which contributed to the banking crisis.

\section{Virtues and vices in the financial sector and the national discourse}

Obviously, the starting point and central focus in this investigation was the morality and work practice within the banks and the interaction with their customers, shareholders and regulators. This analysis has several moral dimensions but I take my example here from descriptions and self-descriptions of the characteristics of the Icelandic bankers. This example draws upon the basic moral features of virtues and vices. It has been argued that moral failures, such as greed precede and partly cause a financial crisis (Weitzner \& Darroch 2009). In the WGE analysis, the emphasis is on the interplay between the system of incentives and bonuses in the banks and the conduct of individual bankers. In this way, greed as a moral vice is not regarded as a primary phenomenon but rather as a symptom of and a product of a social system. In this way, the reference to greed as an individual characteristic is still regarded as meaningful but it loses its explanatory power unless it is linked to a larger context of motivational factors which could have been subject to regulation.

The discussion of virtues and vices is also related to structural changes in the banking system as well as the generation change that took place in the banks in the wake of their privatization in 1998-2003. The structural change was the transformation of traditional savings and loans institutions to financial investment banks. The mentality of the new generation of investment bankers was radically different from the traditional bankers who did not suit the new business model. As a consequence, the fine balance that there has to be in a bank between the adventurous expansionists and the more conservative bankers who provide the reality check was threatened. ${ }^{6}$

In the social discourse surrounding the new generation of investment bankers, the apparently praiseworthy characteristics of these young males was quite prominent. A typical description was that they were courageous, hard working, optimistic and swift acting men who were determined to succeed. In an interview with the English newspaper The Guardian, the Icelandic president, Ólafur Ragnar Grímsson, likened the success of the Icelanders to well-known historical examples of innovation and flourishing: «It all seems rather unlikely», the reporter writes, «but Grímsson puts forward an endearing explanation»: «When we look at renaissance Florence, renaissance Venice and even classical Rome and classical Athens, they were all about the same size as Iceland is now. It is an important lesson of history 
that small creative communities can do extraordinary things.» (The Guardian, November 20, 2005). The president gradually developed his own theory of the unique qualities of the Icelandic bankers with roots in the Icelandic conditions and heritage (see, for example, Grímsson 2003: 5-6).

This is one example of the rather arrogant nationalistic discourse about the success of the Icelandic bankers. One of the characteristics of that discourse was a reference to the Vikings. The Minister of Economic Affairs wrote, for example: «Energy, courage and solid knowledge of the outreaching Icelandic bankers has brought more and faster investment success abroad than was possible to foresee and the Viking has caught international attention.» (Sigurdsson 2007) University scholars analyzed the simile: «The 'Viking ship' is what gives Icelandic business men a competitive advantage: decision-making is fast, lines of communication are short and the pattern of interaction is open, everyone is ready to work hard for a short time as in the fishing season, there is a strong net of relationships and the 'fixer gene' flourishes.» (Adalsteinsson \& Gudlaugsson 2007: 2).

However, the characteristics of the Icelandic bankers were not always described as virtues, even though they were painted in appealing colors. An example is when the director of the Icelandic Chamber of Commerce explained the success of Icelandic businessmen. He provided three major explanations: (i) the strong pension funds in Iceland; (ii) the deregulation of the financial sector; (iii) the way in which Icelanders do business, «something which some people have characterized as «effectively crazy», some power and resoluteness which enables them to succeed.» ${ }^{7}$

In retrospect, the success obviously needs to be reevaluated and also the highly praised characteristics that were said to contribute to it, in particular insofar as they were regarded as virtues. Moral virtues are praiseworthy character traits exhibited in human actions. They are distinguished from mere capacities or strengths of character by their intrinsic relationship to valuable aims. As Philippa Foot has argued, the strength that enables people to overcome obstacles such as fear is not the virtue of courage unless it brings about good actions: «just as poison, solvents and corrosives do not always operate characteristically, so $[\ldots]$ courage is not operating as a virtue when the murderer turns his courage, which is a virtue, to bad ends». (Foot 1978: 16).

Clearly, the «virtue-words» that were used to characterize the expansionist in the banks did not refer to character traits which bring about valuable ends and thus were not operating as virtues. To the contrary, among the results from the WGE is the finding that the characteristics which were seen as the main assets of the Icelandic bankers contributed to their demise. Thus the 'fast decision making' turned out to be rashness and incautiousness, the 'close net of interaction' resulted in cross ownership and the energy associated with courage propelled high risk taking which is an indication of foolhardiness. These character traits became particularly damaging because 
of the culture of self-regulation that was relied on in the banks. Ironically, the Viking simile seems to invite a very different lesson than the one which was popular in the apparently prosperous time of the banks. The saga narratives from the Viking age show for example how much damage individuals could inflict on a stateless society and how ineffective the men of good will were in securing the conditions for orderly existence (Árnason 2009).

\section{Lack of principles and professionalism in the administration}

This short description of how virtues enter the moral analysis of the WGE reveals both the limitations of virtue ethics and the limits of individual character traits in sustaining morality. The virtues have to be enlightened by ethical principles and complemented by a structure of moral rules and enforceable obligations. I will draw upon the analysis in the WGE report to show how a lack of strict enforcement of rules and compliance with good work practice resulted in the fact that bankers were able to go to the excesses that made the banks so vulnerable to the international crisis. The example concerns the style of the main regulatory institutions, the way in which regulators interacted with the bankers.

The two main regulatory agencies in the financial sector in Iceland are the Financial Supervisory Authority (FME) and the Central Bank of Iceland (CBI). The director of the FME took a cooperative approach to the banks on the presumption that they shared the common interest of maintaining a stable financial environment. He also worked on the assumption that the directors of the banks were honest people since they would have both financial and reputational motivation to adhere to good banking practice. ${ }^{8}$ These assumptions formed the basis of trust between FME and the banks. This trust seems to have been one-sided, however, because the position in the banks was to «fight the regulators» when they visited the banks. ${ }^{9}$

The assumption of the FME director that the bankers were «honest people» can be seen as rather naïve given the experience of banking. The first lesson listed in a report about lessons learned from a financial crisis is: «There are powerful incentives for people with questionable reputations to control banks.» (Lemieux 1999: 4) Moreover, banking in Iceland, in particularly investment banking, has a short history and there had not been time to cultivate a trustworthy banking culture with a strong internal regulatory framework. On the contrary, the transformation of the Icelandic banks from local savings and loans institutions to international investment firms brought about a generation change in the banks. In 2004, 41 percent of bank employees in the country had five years experience or less and 21 percent had no more than two years work experience. ${ }^{10}$ It has even been stated that 
there was a policy to get rid of those who had traditional banking experience and knowledge. ${ }^{11}$ They did not fit into the new culture where there was considerable pressure that everyone would think alike. As one of the bank directors of Kaupthing bank said: «It is very hard to change a culture without changing employees». ${ }^{12}$

The new culture was not conducive to trustworthy self-regulation. An experienced and well respected foreign compliance officer who worked in one of the Icelandic banks for a short period in 2007, described the atmosphere in the bank as «cultish». There was a lack of professional detachment, members of the staff were strongly devoted to the institution. The prevailing attitude was that growth was more important than following the rules in every way. There is an inevitable tension in banking between doing things right and doing them quickly. In this particular Icelandic bank it was more important to do them quickly. There was a lot of pride both within the bank and in society at large which clouded the judgment of decision makers. The compliance officer got the impression that Icelandic bankers saw themselves as doing something unique and they were not listening to an «outsider» like him. Generally, the role of compliance officers was downplayed in the bank. They were kept busy with minor errands but were not enabled to get the whole picture of how the bank was being run. ${ }^{13}$ Moreover, compliance officers in the banks criticized the FME for not supporting them in their attempt to strengthen their status in the banks. It is indicative of the status of compliance officers that there was one compliance officer in Glitnir bank in Reykjavík, but there were 13 employed in the travel and entertainment department in that bank. ${ }^{14}$

In light of this, the trusting approach of the main Icelandic regulator does not seem to have been well founded. Rather than relying on the honesty of the individual bankers and their presumed interest in prudential behavior, there was a need for more emphasis on the moral principles of good banking practices and to ensure compliance with them. The WGE argues that it is one of the weaknesses of a small society that there is a lack of professional distance and detachment which is needed for efficient regulation. The impersonal space created by objective moral rules which protect the values at stake is especially important in a situation of personal proximity and close connections. This was all the more needed since the legal framework was rather slim. Iceland is a member of the European Economic Area and thus is subject to the same minimal legal framework as EU member states. Icelandic authorities did not make use of the leeway provided in that framework to adapt the regulations to the national conditions. As a consequence, the banks grew out of proportion and became too large to be managed by the local regulators.

The WGE observed that legalistic thinking was characteristic of the Icelandic regulators where the letter of the law or emphasis on isolated articles 
is more important than the purpose of the law. A striking example of this is when the British and the Dutch regulators were trying to limit the activities of the savings accounts Icesave in the Icelandic Landsbanki. While the Dutch and British authorities were worried due to the weak securities that these savings accounts would have in a small country, the spokesmen of the FME argued that it was illegal to restrict the operation of the Icelandic bank. ${ }^{15}$ Later, the director of the FME said that the Dutch had been voicing macro-economic worries, while FME had paid attention to whether the Landsbanki was breaking any law. ${ }^{16}$ The main purpose of the law is to protect the interests of the public, but a rigid appeal to individual letter of the law can mainly serve special interests. An economist at the CBI commented on this mode of thinking: «It seems to me that there was a basic misunderstanding about the point of financial regulation here in Iceland. [...] That it was the role of these authorities to see to it that existing laws were complied to each time. So you are watching the financial system fall off the cliff, and if it is done according to the law, then that's just fine». ${ }^{17}$ In a report from the British Financial Supervisory Agency on the role of regulatory agencies, it states that: «Regulatory and supervisory coverage should follow the principle of economic substance not legal form.» 18

This shows that there is a strange gap in the work practice of FME between the reliance on personal qualities on the one hand - the trust in the bankers' honesty - and a rigid appeal to the letter of the law on the other hand. The moral space in between is the field of moral rules and principles that are there to guide good financial practice. This is not to be regarded as opposed to the law. There is an important clause in Icelandic law which guides the activities of the FME to the effect that financial firms are to act in accordance with normal and sound business practice and customary conduct on the financial market. ${ }^{19}$ This clause about normal and sound business practice implies an appeal to moral principles which need to enlighten the judgment of the regulatory agencies which have the main purpose of protecting the public interests.

The WGE observed a similar kind of moral void in the practice of some members of important professions within the banks, especially the lawyers and accountants. Contrary to the mission of acountants to «serve the public interest» as it is described in their international code of ethics, it seems that some accountants in the banks were primarily concerned with serving their individual clients. This is contary to a fundamental principle of accounting as the members of that profession have declared: "A distinguishing mark of the accountancy profession is its acceptance of the responsibility to act in the public interest. Therefore, a professional accountant's responsibility is not exclusively to satisfy the needs of an individual client or employer.» ${ }^{20} \mathrm{It}$ is part of the legalistic thinking described above to use the law strategically as a means to reach a desired goal, even regardless of the social consequen- 
ces. The moral mission of a profession, however, requires moral thinking where the individual actions of the professional need to be evaluated in light of the public interest.

It is one of the conclusions of WGE that proper professionalism was largely lacking both in the banks and in the supervisory agencies. One of the striking aspects of this is that the technical legalism is not a break from mainstream thinking but rather a symptom of a widespread mentality which is hostile to an appropriate understanding of social responsibility (Cf. Argandoña 2009).

\section{The stewards of public interests. Moral obligations in the political sector}

In an interview about the international financial crisis, ${ }^{21}$ Jürgen Habermas says: «Politics turns itself into a laughing stock when it resorts to moralising instead of relying upon the enforceable law of the democratic legislator. Politics, and not capitalism, is responsible for promoting the common good.» Habermas argues that while private actors are driven by «the socially recognised logic of profit maximisation», politicians have the primary obligation of protecting and furthering the public interest. Hans Jonas likens political responsibility to paternal responsibility; «The 'statesman', in the term's full sense has, for the duration of his office or his power, responsibility for the total life of the community, the 'public weal.» (Jonas 1984: 102).

I will not enter into the discussion here to what extent private companies are to have social responsibilities (see on this, for example, Nordal 2009). It is sufficient to say here that the social responsibility programs of the Icelandic banks were geared towards sponsoring cultural events, student's grants, sports and charity. While these programs may have brought about beneficial social results they primarily strengthened the image of the financial sector and facilitated the view that the private sector was indispensible for sustaining a thriving culture in the country. These programs also played a key role in getting the owners and directors of the banks into the spotlight as benefactors of the public. The irony is that at the same time the high risk policies of the banks were threatening the very economic structure of society.

The discussion of obligation of politicians and their responsibilities has several dimensions in this context. First, regarding their role in facilitating the growth of the banks and enabling them to become international investment firms. Second, in failing to heed signals of a major financial banking crisis and not taking actions to prevent it. Third, in taking a stance with the private sector instead of protecting the public interest. I will discuss each of these briefly in light of the analysis from the WGE. 
The first aspect of the political obligation concerns the political agenda that was implemented with the privatization of the Icelandic banks and the concomitant deregulation of the financial sector. The working practices in relation to the process of privatization were seriously flawed which is made manifest most clearly in the fact that the principle of distributed ownership that was to be the backbone of the process was discarded. The two state banks were each sold to a small group of individuals with large shareholdings and little banking experience. These two groups were each favored by one of the ruling political parties at the time so the privatization ended up as a political deal aimed to maintain the balance of power and influence. At the same time, a major theme in the justification of privatizing the banks was that the corruption related to political influence in the banks had to be uprooted and that this would be done by letting the laws of the market reign. However, the way in which the privatization was done paved the way for cross-ownership and mutual lending relationships which were largely hidden in a complex and non-transparent structure of companies and ownership.

As mentioned before, the Icelandic state adopted the minimal framework of the EEA regarding the financial market but did not implement national legislation to adapt it to the conditions of a small country. The prevailing tone in politics was that «unnecessary laws and regulation» regarding the financial market had to be removed and that supervisory agencies should not make things difficult for the financial firms. ${ }^{22}$ Even in 2007, the declaration of the new government emphasizes that the financial sector should be enabled to grow and extend its activities into other market zones while it should be in the interest of the ever larger banks to have their home base in Iceland. The financial sector had become one of the pillars of the Icelandic economy and the politicians saw it as their role to facilitate its growth and prosperity, surely believing that it would benefit the Icelandic population as well. This belief was reinforced by positive reports from the Icelandic supervisory institutions, many international ratings firms and analysts. The soil for critical voices was not fertile.

Lars Christensen, chief analyst at Den Danske Bank and one of the authors of the 2006 Geyser report which showed many weaknesses in the standing of the Icelandic banks, ${ }^{23}$ observes that «the main problem in Iceland was the pervasive collusion: politicians, public officials and regulators were all in the same time team. Those who were supposed to protect the economy and the public interests were the cheerleaders of the expansionist in the banks. [...] There was no independent voice. In response to criticism like the Geyser report, everyone united as «we» against «them», as if there was a conspiracy to damage the Icelandic banks.» ${ }^{24}$ Instead of critical thinking and responsible distrust, a strong sense of solidarity, mutual trust and «co dependency» was characteristic of Icelandic politicians' relations with the bankers, according to Christensen. 
The WGE analysis of media material demonstrates how politicians consistently showed solidarity with the bankers and had trust in them. This is particularly clear when politicians were responding to foreign criticism or warnings of the weak standing of the banks. Their response is characterized by the following three main features. First, the criticism is traced to spurious motivation, such as envy of the success of the banks and ill will towards Icelandic bankers. This is especially striking in the case of Danish criticism, but the Danes persistently asked the simple question, reminiscent of H.C. Andersen' tale of the Emperor's clothes: «Hvor kommer pengene fra?» (Where does the money come from?). Finn Mortensen, business editor at the Danish newspaper Berlingske tidende, said in an interview ${ }^{25}$ that the main reason why the Danish media had been so criticial was that they did not get the same kind of information about the running and ownership of the Icelandic companies that they are used to having access to when they report about Danish business.

The second characteristic feature of the political response of Icelandic politicians to foreign criticism is that the problem is one of image and perception which need to be corrected. In order to do that, Icelandic ministers travelled abroad and held news conferences where they gave reassuring speeches to skeptical reporters. According to Rene Kallestrup, ${ }^{26}$ specialist at the Copenhagen Business School and former researcher at Danske Bank and the Icelandic Central Bank, the most serious side effect of these «road shows» was that it intertwined the credibility and trustworthiness of the Icelandic state with that of the banks and thus gradually transferred the risk more to the Icelandic public.

The third main feature of the response of Icelandic politicians to foreign criticism is that they referred to stress tests of the monitoring agencies and to commissioned reports about the standing of the Icelandic banks. In the wake of the international financial crisis, many have argued that the stress tests performed on banks were of little use and may even have been damaging because they gave false assurances that the banks standing was better than it was (Gudmundsson 2009: 30). ${ }^{27}$ The main reason for this is that these tests focused on individual banks, while their interrelations and important structural factors were ignored. One report, commissioned by the Icelandic Chamber of Commerce in 2006, played a major role in giving assurances to both Icelandic politicians and the international community at a critical time in the period leading up to the collapse of the banks (Mishkin \& Herbertsson 2008). ${ }^{28}$ According to Gylfi Zoëga, ${ }^{29}$ professor at Department of Economics at the University of Iceland, this report played an important role in enabling the Icelandic banks to have access to foreign markets which in the long run made the situation worse because the banks grew even larger. After that it became more difficult to deal with the problem. 
But the main example that WGE uses in its analysis of how politicians failed to meet their moral obligations and defend the Icelandic public draws upon interactions between the key ministers in the government and the members of a consultation group which was set up by the Icelandic authorities to take precautionary measures and work with the political authorities in order to prevent a financial crisis. The consultation group gathered first in 2004 but it was formally established in 2006. Its members were the permanent secretaries of the Ministry of State, the Ministry of Finance and the Ministry of Economic Affairs, the director of the Financial Supervisory Agency (FME) and one of the directors of the Central Bank of Iceland (CBI). These key institutions which had the common task of preserving economic stability in Iceland were supposed to coordinate their actions in the event of a financial breakdown. ${ }^{30}$

The notes from the meetings of this group tell an interesting story of what was going on behind the scenes in the Icelandic administration before the banking crisis. The WGE summarizes its analysis of this example in six symptoms of bad working practice and weak political morality which I will briefly describe:

(i) Independence of public officials from politicians. The members of the consultation group were high ranking public officials. It seems clear that they did not always inform their political ministers properly about the issues that were discussed in the consultation group. From a moral point of view it is important that public officials have a professional independence with regard to their political bosses. By a professional independence is meant that a public official is to be respected to see dedication to public service as his/her primary obligation and that is not be sacrificed for a service to a misuse of political power (Cf. Kristinsson 2007). But the kind of independence of public officials demonstrated in the current example is not of this kind, rather that they do not trust certain ministers, show neglect in informing them about crucial issues and thus assuming more power than they are expected to have or can legitimately claim.

(ii) Lack of initiative and pointing towards the responsibility of others. The consultation group discussed the necessity to downsize the banks. A British expert in financial stability, Andrew Gracie, had been working with the group and given advice about how to put the directors of the banks up against the wall in order to make them take action. But this was a task for politicians and/or directors of the supervisory agencies and it was never done. ${ }^{31}$ There is a common theme in the words of politicians and some of the high ranking public officials that reported to the SIC that it was not their role to take any action against the banks. The politicians point to the CBI, the CBI points to the FME and the FME says that the laissez faire political mentality prevented a action from being taken against the banks. «We never received any suggestions for actions», said the leader of one of the two ruling 
parties, the minister of state, and points towards the CBI. ${ }^{32}$ She also emphasizes that it was by no means the function of the ministry of state to deal with these matters. The prime minister said that the consultation group did not call for any action from politicians; moreover «there was nothing there that was in the power of the authorities in my opinion». ${ }^{33}$

(iii) Damaging effects of political appointments. One of the key figures on the scene in the years preceding the fall of the banks was the chair of the Board of Governors of the CBI who had formerly been a prime minister in Iceland for 13 years. The governor had been prime minister during the privatization of the banks. His role in relation to the fall of the banks is somewhat tragic. As the main governor of the CBI he heard the criticism of his colleagues abroad about the irresponsible conduct of the Icelandic bankers. But in his attempt to convey this criticism to Icelandic politicians he suffered from a lack of trust, not only from former political adversaries but also from his political allies. This is partly because of his informal manner of speaking which he adopted because he is at home in the system. «This made things enormously complicated for me», says the prime minister, and states that he would have listened in a different way to warnings from a governor who had never been in politics. ${ }^{34}$ Some high ranking public officials had been hired by the governor of CBI as a former prime minister and seem to have been even more loyal to him than to their political ministers.

(iv) Lack of professional work practices. Perhaps the most striking mark of poor work practice in public administration is how negligent the public officials and political ministers were in gaining information as a base for their decision-making and planning. The consultation group did not have access to information about ownership of the banks or about their main debtors. This information was necessary for them to make the assessment needed about the standing of the banks. This is one of the reason why the work of the consultation group was not of much use when the banking crisis occured at the end of September 2008. Another reason was that there had been resistance in the group to form and develop scenarios of a possible financial breakdown and prepare a response to them. This is a standard methodology for task forces of this kind. According to the permanent secretary of the Ministry of Finance, such scenarios are an academic exercise at best and they would be of no significance in reality. «Decisions were made when they eventually had to be made». ${ }^{35}$

As Aristotle pointed out it is, of course, correct that in practical matters the decision can never be completed unless one knows the unforeseeable nuances of the situation, ${ }^{36}$ but that does not diminish the need for a careful deliberation and scrutiny of options. In fact, the less prepared decisions are, the more leeway there is for powerful political players to follow their own agenda when «decisions have to be made». This way of working also invites distrust and suspicion because it is hard to show that a serious and 
trustworthy effort had been made to make a well reasoned and sensible decision. The important decision about the take-over of Glitnir bank by the Icelandic state at the end of September 2008 was made without careful calculations or assesment about the effects of that decision upon other Icelandic banks (which the state had to take over a few days later). The decision was not compared to other thought-out options or possible consequences of them. It was not a well-grounded decision. The Minister of Economic Affairs, who was distrusted, was not present at the weekend when this crucial decision was made. Nor were the chief economists of the CBI who read about the events in the newspaper the morning after. ${ }^{37}$

When this momentous decison was made, the ministers present had very little written information on paper before them. This is indicative of a very poor level of documentation in the Icelandic administration, at least in its uppermost level that was mainly under scrutiny in this investigation. In the judgment of the WGE, this is another symptom of the smallness of Icelandic society. In specific terms this is evident in the close personal relationships and informal interaction that it breeds between key players on the financial scene, public officials and political ministers. Informal persuasion was commonly used by the CBI in its dealings with bank directors rather than written notes or memos. Minutes were usually not made in meetings between governors of the CBI and key ministers in the government. As a consequence, it is very hard to discern in retrospect who said what to whom and when. One reason for this lack of documentation was the prevailing distrust; the chair of the consultation group said, for example, that the group had never prepared anything written for the government because we «did not want this discussion to spread out». ${ }^{38}$ There was a suspicion of leaks from the government. This also contributed to the fact that the issue of the banks, let alone a possible banking crisis, was never discussed around the government table. This is also explained by the fact that individual ministers are invested with extensive authority in the Icelandic constitution (Kristinsson 2007: 210). Another reason for the lack of documentation was the fear that things would become worse if they would become publicly known.

(v) Lack of independence towards the financial sector and fear of causing a crisis. Before the crisis the governor of the CBI gave a report to the prime minister about the serious concerns of his European colleagues about the standing of the banks after a meeting in London in February 2008. According to the governor, the prime minister said when he was asked for his reaction to these concerns: «We have called in the bank directors and they say that this is not correct, that things are in order.» ${ }^{39}$ This response is indicative of the naive trust and co-dependence of the key politicians in Iceland with the directors of the banks. This co-dependence was psychologically reinforced by the fear of causing problems for the banks and even being bla- 
med for their fall. «We were always very afraid that efforts to downsize the banks would cause the banks to fail», stated the Minister of Economic Affairs. ${ }^{40}$ This fear has strange consequences. On the one hand, it indicates that politicians knew how serious the situation was; on the other hand it leads them to give misleading information and thus inadvertently making the problem worse. By focusing on the danger of a run on the banks, they neglected the historical fact that bankers are known to behave desperately when they sense downfall and become excessively risky (Cf. Hellman, Murdock \& Stiglitz 1997). The last months before the failure of the banks turned out to be extremely costly, partly because of the loans with poor securities from the CBI to the sinking banks.

(vi) Political paralysis. Fear has paralyzing effects and it is a measure of courage how it is responded to. According to the director of the FME, fear was the main reason why preventive measures were not taken on the basis of the advice of the consultation group. He points to a crucial paradox which throws light on the inaction of the authorities: The decision to increase the foreign currency reserves would not have been made if the policy had not been not to save the banks but that was in contradiction to the words of the politicians that the state would stand behind the banks. ${ }^{41}$ The Minister of Finance echoes a similar position: We were not willing to define the last resort role of the CBI precisely, so as not to be stuck with a particular definition when it came to the test. ${ }^{42}$ There was a major disagreement within the administration about the matter to what extent Icelandic state would be responsible for any of the banks' debts if they would fail. This crystallized in the Icesave issue, large savings accounts in branches of the Icelandic Landsbanki in both Britain and the Netherlands. Icelandic authorities, both public officials and politicians, had repeatedly said that the Icelandic state would stand behind the banks and the good ratings of the banks had always been related to the credibility of the Icelandic state. However, the authorities did not (i) seek an independent legal report about the duty of the state to stand behind these savings; (ii) get information about the size of the possible financial commitments (iii) take resolute action towards the banks that would put pressure on them to move these accounts into a subsidiary company which would not have securities in the Icelandic state.

The WGE concludes that these six features of weaknesses in the work practice of the Icelandic administration and its exchange with political ministers demonstrate that these guardians of public interests did not serve their roles properly. The responsibility to protect the common interests of the public is implied in their roles regardless of how their function is legally defined. Role-specific responsibility is relevant when we are evaluating which moral obligations people have by virtue of their social roles and positions (Cf. Young 2006: 119). It is the responsibility of people who take on social roles to oversee a certain sphere of practice and make sure that they 
are functioning, even regardless of specific actions or omissions on their own behalf, for example as ministerial responsibility is understood in some countries. ${ }^{43}$ It is far too narrow to focus on particular actions or inactions which is most important when criminal offence and concrete culpability is being estimated.

It seems clear, however, that Icelandic politicians and public officials did not take appropriate actions within their power to protect the interests of the public, by attempting to avoid the collapse of the banking system or soften the crisis. They neither sought sufficient information nor heeded warnings about weak standing and even failure of the banks. Icelandic politicians did not exercise critical thinking which is a precondition for independent action. It is the hallmark of critical thinking not to become convinced about the truth of a statement without having good reasons for believing it (Clifford 1961). However, there are well-known dynamics of human behavior which act against the demand of critical thinking and the WGE commissioned a report on political psychology and herd behavior from an expert on that matter. ${ }^{44}$

\section{Moral values and mentality in the socio-cultural sphere}

In addition to analyzing morality and work practice in the banking sector and in the sectors of regulation and politics and assess how they have contributed to the fall of the banks, the WGE attempted to place these events in the context of social values and cultural mentality in the last couple of decades in Iceland. During this time, major structural changes took place in Icelandic society. Before the collapse of the Icelandic banks, an historian/ journalist published a book entitled New Iceland. The art of losing oneself (Magnússon 2008). The author argues that Icelandic society has gradually been changing from a relatively egalitarian community to a society where a proportionally large group of newly rich people makes an impact on others with their lifestyle, attitudes and values. These people showed off in a way that older generations of rich people never did demonstrating a luxurious lifestyle not known before in Icelandic society.

The conditions for this change were created by some crucial political decisions, such as Icelandic partnership in the EEA (1993), the uptake of marketable quotas in the fishing industry (1990) and privatization of the banks (1998-2003). Along with this, decisions were made about deregulation of the financial sector and changes in the tax system that were favorable to business and financial institutions. All of this boosted the financial sector which soon became, along with fisheries and industry, one of the three main pillars of the Icelandic economy. Ideas about making Iceland an internatio- 
nal financial center were afloat and in the ruling circle the guiding vision of Iceland as a land of liberty and competitiveness was pervasive.

A very clear statement of this vision is to be found in a report from 2006 of the Icelandic Chamber of Commerce entitled «Iceland 2015». ${ }^{45}$ The main message in this report is that the state, not the banks, needs to downsize. Solutions are to be sought in privatization of many of the functions that are currently done by the state and in line with this it is explicitly stated that Iceland should no longer compare itself to other Nordic countries, because it had already exceeded them in most regards taken to be of importance in the report, i.e. indicators of competitiveness.

Some economists had argued, however, that the lack of competition was a major problem in Iceland because of the few and large players on the market. ${ }^{46}$ Small family companies had been bought up by the larger companies and a few corporations were accumulating wealth and power unprecedented in Icelandic history. In light of this description, it is tempting to use the term corporatism about the developments that took place in Iceland in the wake of deregulation and privatization of the financial and economic sectors. According to Naomi Klein, the «policy trinity» of the ideology of corporatism consists of aiming at (i) the elimination of the public sphere; (ii) total liberation for corporations; (iii) skeletal social spending (Klein 2007: 15). Two of these conditions were clearly in place in Icelandic and the ruling ideology was to further undermine the state institutions. It is a characteristic feature of ideology that it stifles thinking and blurs the perception of reality. What matters here is not to what extent this vision had been incarnated in Icelandic society - that is a matter of further empirical investigation - but rather how this ideology fed into crucial political decisions and sustained the belief of politicians and policymakers that things could work out in spite of warnings to the contrary.

It is a strikingly common feature of the social discourse in these years to use the superlative adjective. Iceland was the most free and most competitive country and in this way became the «best in the world». A key chapter of 90 proposals from the Icelandic Chamber of commerce captures the message in a nutshell: «Increased leeway for the business sector to regulate itself is a progressive step favored by the Chamber of Commerce. Until now, increased freedom for self-regulation has proved very effective so there is no reason not to continue on that path. Therefore, it would be much more sensible to let players on the market set their own rules and implement them rather than rely on public regulation which is burdensome and costly. In this context, it should be pointed out that the effectiveness of the public supervisory institutions, such as FME and the Competition Authority, should be increased». ${ }^{47}$ Effectiveness was the euphemistic term for the laissez faire policy preached by the main stakeholders in the financial sector, supported by many intellectuals, especially at the semi-private University of 
Reykjavík which is partly owned by the Chamber of Commerce, and implemented by the politicians.

The primary moral value behind the social changes I have described is one of liberty or freedom. Freedom in this context is understood primarily in a negative sense of having space where one is free from interference or external control (Cf. Berlin 1969: esp. 121-124). Ideas about how the actors are to gain personal autonomy or independence within that space are not emphasized. This means in effect that morality in the sense of self-regulation in light of moral rules, values, virtues and obligations is neglected. At the same time, there is a repeated reference in political speeches about the responsibility that must accompany this increased freedom. But instead of making a policy which would be conducive to assumption of responsibility within the business sector, e.g. by strengthening the supervisory institutions and the structure of regulation within the banks, the emphasis is on individual trust and the relationship between the political sector and the business sector is moralized on an individualistic level.

A telling example of this is a reaction of the Icelandic prime minister in 2003 to news about contracts with bank directors about unprecedented high bonuses and salaries. The prime minister showed his disapproval by personally withdrawing his savings from his account in the bank and used the occasion to voice moral criticism of the bankers. Instead of taking an action in his power as prime minister, «relying upon the enforceable law of the democratic legislator», as Habermas put it in the above quote, he acted as a private person taking a moral stance. This is, therefore, a symbolically pregnant action which demonstrates in a nutshell the prevailing ideas of freedom and responsibility. The policy was not to narrow the leeway for banker's action by regulation and sanctions but appeal to their moral sensibility. They ought to behave properly! This is fully in accordance with the defensive strategy that it was not the ideology or the institutions that failed, but the people: «In some respects it can be said that it was unfortunate what kind of people went into the banks. They were talented men in every regard, but they were fascinated with enormous profit». ${ }^{48}$

The emphasis on freedom as non-interference is related to a belief that it will bring about economic prosperity, since individuals will be provided with optimal conditions to maximize profit and consumption which will bring wealth to the entire social body and happiness to the citizens. At the same time, the institutions of the state which provide many of the necessary conditions for human flourishing were gradually undermined. The prevailing vision of the people was to see them as consumers with a maximum liberty for consumption while the conditions for what Amartya Sen characterizes as «relevant freedoms» were neglected: «The relevant freedoms include the liberty of acting as citizens who matter and whose voices count, 
rather than living as well-fed, well-clothed, and well entertained vassals.» (Sen 2000: 288).

And for a while most people seemed to profit from the state of affairs, referred to in Icelandic as "góðæri» or «time of prosperity». ${ }^{49}$ It has been argued that, even in economic terms, this is a misnomer, because the prosperity was like a house of cards, built on loans and had no real economic foundation (Ólafsson 2008). Nevertheless, the times were characterized by an excessive consumerism in the country and many Icelanders used the opportunities that opened up for an unprecented access to loans as well as new ways of saving with higher interest than had been known before. During the economic boom, Icelanders could free themselves from the lowest paid jobs in the service sector, leaving them to foreigners. Travelling abroad became relatively cheap, largely due to international changes in air travel but also to the strong standing of the national currency. As Kaarlo Jännäri, former Director General of the Financial Supervision Authority has observed: "The nation, up to its highest echelons, supported and admired the banks, and many are still in a state of denial regarding their own part in this tragedy. [...] [T] he overall national pride in the success of the banks would probably have made it futile even to try while the going was good and success followed success. By the time the tide turned, it was too late, and there was too little that could be done to avoid catastrophe.» ${ }^{50}$ The problem was created when the banks were allowed to grow out of proportion and fill themselves with loaned money.

This raises the question of collective responsibility: How did Icelanders in general contribute to a process and enable certain practices which they benefited from? In discussing this complex question, it is crucial to distinguish this «social connection model of responsibility», as Iris Marion Young calls it, from both role specific responsibility and even more sharply from the liability model of responsibility (Young 2006). From this point of view, the statement «we are all responsible for what happened» does not necessarily imply the view «we should not look for culprits», unless we take the latter to mean that some individuals bear all the responsibility for what happened. However, the social connection model mitigates liability in the sense that no-one is to blame for social structures. Everyone is implicated in a system of global capitalism where, as has been argued, «the problem with the system is the system itself». 51 The important task is to give all threads in this complex web their proper due, recognizing the enveloping macro structures without losing sight of individual liability and role-specific responsibility within the structure.

Moreover, the idea that «we all» bear responsibility in the sense that we benefitted from the state of affairs and contributed to it through some of our actions, however small that contribution is on the large scale, does not mean, of course, that everyone is responsible to the same degree. As Young 
argues, «the power to influence the processes that produce unjust outcomes is an important factor that distinguishes degrees of responsibility» (Young 2006: 125). The power to influence relates partly to knowledge and most members of the public were probably unaware of what was taking place. This is one of the reasons why the public outrage in Iceland has been so strong against having to pay for the Icesave debts. The argument is that ordinary citizens should not pay for the debts of private bankers. However, banks are no ordinary firms and in democratic societies the citizens must eventually assume responsibility for the actions and negligence of the authorities they have chosen to handle their affairs. The Icesave accounts were in Icelandic banks practicing abroad, they were primarily subject to Icelandic regulation and the Icelandic FME was not cooperative when British and Dutch authorities tried to intervene. Icelandic top politicians repeatedly confirmed that the state would back up the banks. From a moral point of view, it is therefore unfair to try to seek refuge in a court of law or to say that the Icelandic nation is being bullied. That strategy has fed into a damaging nationalistic mentality which before the crisis characterized Icelanders as victors and now as victims.

The question of common responsibility inevitably places the media into focus. Accurate reporting and critical questioning is a prerequisite for the shared knowledge and public reflection that societies and individuals need in order to understand the complex environment and workings of contemporary society. In addition to reflecting on the role of the media in feeding into the prevailing mentality which made both the public and politicians benumbed to what was happening, the WGE summoned a special analysis on the reporting of the Icelandic media during the last two years before the crisis. The main result is that the way the media framed the public discussion and the portrayal of the banks and their continuous expansion was primarily positive. ${ }^{52}$

It is important to note that responsibility is not only retrospective but even more importantly in this context prospective. The real test of the common responsibility of the Icelandic nation is how the citizenry will respond to the current situation and to information about its complex causes. The WGE concludes its analysis by saying that it demonstrates pervasive and deep-rooted weaknesses in the structures of the democratic society. Although several individuals, in the financial, administrative, political and the public sphere, showed negligence and sometimes reprehensible action which needs to be sanctioned appropriately, the most important lessons are about weak social structures and public institutions. It is the common responsibility of the Icelandic nation to work towards strengthening them and build a well-functioning democratic society. 


\section{Notes}

1 See the website: www.rannsoknarnefnd.is/category.aspx? catID $=27$

2 Law no. 142/2008, article 1.

3 The members are: Vilhjálmur Árnason, professor of practical philosophy at the University of Iceland (chair), Salvör Nordal, a philosopher and director of the Centre for Ethics at the University of Iceland, and historian Kristín Ástgeirsdóttir, former parliamentarian for the Women's movement and current director of the Equal Status Council in Iceland.

4 An Executive summary in English of the report can be found at the website of the Icelandic parliament: http://sic.althingi.is/

5 For a discussion of this tendency of applied ethics in another context, see Árnason \& Hjörleifsson 2007.

6 Lars Christensen, chief analyst at Den Danske Bank. Interview with author, Copenhagen April 30, 2009.

7 Finnur Oddsson in an interview with The Icelandic financial newspaper, Vidskiptabladid September 14, 2007. The words «effectively crazy» are in English in the interview which otherwise is in Icelandic.

8 Director of the Icelandic Financial Supervisory Authority. Report of the SIC, Vol. 8: Ethics and Work practice, p. 121.

9 Compliance officer at Kaupthing bank. Report of the SIC, Vol. 8: Ethics and Work practice, p. 120.

10 Editorial in the monthly business magazine Frjáls verslun [Free trade] 2/2004.

11 A tax lawyer of Landsbanki. Report of the SIC, Vol. 8: Ethics and Work practice, p. 191.

12 «Eftir höfðinu dansa limirnir» [The limbs dance after the head]. Interview with Ármann Thorvaldsson in the newspaper Fréttabladid October 25, 2006.

13 Compliance officer from Kaupping bank: letter to author, October 202009.

14 Compliance officer from Glitnir bank. Report of the SIC, Vol. 8: Ethics and Work practice, p. 55.

15 Centre for Financial Law, University of Amsterdam. Report to the Dutch Parliament: De bevoegdheiden van de Nederlandische Bank inzake Icesave. Onderzoek in opdracht van het Miniterie van Financiën. June 11 2009, p. 59.

16 Director of FME. Report of the SIC, Vol. 8: Ethics and Work practice, pp. 123-124.

17 An economist at the CBI. Report of the SIC, Vol. 8: Ethics and Work practice, p. 124.

18 The Turner Review. Regulatory response to the global banking crisis (FSA, March 2009). Introduction, p. 7.

19 Law on financial firm, no. 161 2002, article 19.

20 Code of Ethics for Professional Accountants. The International Ethics Standards Board for Accountants. Website: www.ifac.org/ethics/.

21 «Life after bankruptcy». Interview with Habermas in Die Zeit, November 26, 2008. Available at http://www.signandsight.com/features/1798.html

22 Policy declaration of the new Icelandic government in 1999. Website of the Icelandic state: http://www.stjornarrad.is/Stefnuyfirlysing/

23 Iceland: Geyser crisis. Danske Bank March 21, 2006. Available at http://danskeresearch.danskebank.com/link/FokusAndreIceland21 032 006/\$file/GeyserCrises.pdf.

24 Interview with author, Copenhagen April 30, 2009.

25 The Icelandic financial review, Vidskiptabladid March 6, 2008.

26 Interview with author, Copenhagen May 5, 2009. 
27 The author is former Deputy Head of the Monetary and Economics Department of the Bank for International Settlements in Basel and now governor of the Central Bank of Iceland.

28 Mishkin is a professor of economics at the Graduate School of Business at Columbia University and Herbertsson was at the time a director of the Institute of Economic Studies at the University of Iceland.

29 Interview with author, Reykjavík June 10, 2009.

30 Skilabréf. Viðbúnaður stjórnvalda vegna hugsanlegra erfiðleika á fjármálamarkaði. [Report. Precautionary measure of the public authorities in the event of possible difficulties on the financial market]. February 17, 2006.

31 Director of of the financial department of the CBI. Report of the SIC, Vol. 8: Ethics and Work practice, p. 136.

32 The Minister of State. Report of the SIC, Vol. 8: Ethics and Work practice, p. 140.

33 The Prime Minister. Report of the SIC, Vol. 8: Ethics and Work practice, p. 139.

34 The Prime Minister. Report of the SIC, Vol. 8: Ethics and Work practice, p. 139.

35 Secretary of Finance. Report of the SIC, Vol. 8: Ethics and Work practice, p. 137.

36 Aristotle, Nicomachean Ethics, (many editions), 1112b. Gadamer draws masterly on this in Truth and Method (Continuum 1975), pp. 286-287.

37 An economist at the Central Bank. Report of the SIC, Vol. 8: Ethics and Work practice, p. 144.

38 Secretary of the Prime Minister's Office. Report of the SIC, Vol. 8: Ethics and Work practice, p. 145.

39 Governor of the Central Bank. Report of the SIC, Vol. 8: Ethics and Work practice, p. 139.

40 Minister of Economic Affairs. Report of the SIC, Vol. 8: Ethics and Work practice, p. 148.

41 Director of FME. Report of the SIC, Vol. 8: Ethics and Work practice, p. 149.

42 Secretary of Economic Affairs. Report of the SIC, Vol. 8: Ethics and Work practice, p. 149.

43 Cf. Individual Ministerial Responsibility - Issues and Examples. Research paper of the House of Commons 04/31, April 5, 2004. Available at http://www.parliament.uk/ commons/lib/research/rp2004/rp04-031.pdf

44 Hulda Thórisdóttir: Bound and situated reason. The prelude to and causes of the economic breakdown in Iceland from the viewpoint of research in social psychology. Appendix II to the WGE report.l

45 Ísland 2015. Icelandic Chamber of Commerce February 2006.

46 Thorvaldur Gylfason, professor of economics at the University of Iceland, repeatedly pointed this out.

47 «90 tillögur að bættri samkeppnishæfni Íslands» [90 suggestions for improved competitiveness of Iceland]. Icelandic Chamber of Commerce 2007, p. 19.

48 Governor of the Central Bank. Report of the SIC, Vol. 8: Ethics and Work practice, p. 189.

49 A recent pun has turned this into «óðæri» or «time of madness».

50 Report on Banking Regulation and Supervision in Iceland: past, present and future. 30 March 2009, pp. 22 and 37.

51 A remark made by Rune Skarstein in his talk on the economic crisis at the workshop in professional ethics: «Ethics in a time of crisis», Trondheim, June 16, 2009. See Skarstein 2008.

52 University of Iceland Institute for Media and Communication: Umfjöllun fjölmiðla á Íslandi um banka og fjármálafyrirtæki 20062008 [The media report in Iceland on banks and financial firms 20062008. Appendix I to the WGE report. 


\section{Literature}

Adalsteinsson, G.D. \& Gudlaugsson, T. (2007) Íslensk fyrirtækjamenning: Víkingar í viðskiptum. [Icelandic firm culture: Vikings in business]. Vísbending, 25 (2).

Argandoña, A. (2009) Can Corporate Social Responsibility Help Us Understand the Credit Crisis? Barcelona: IESE Business School, University of Navarra. Available at www.iese.edu/research/pdfs/DI-0790-E.pdf

Árnason, V. (2009) An Ethos in Transformation: Conflicting Values in the Sagas. Gripla XX, pp. 217-240.

Árnason, V. \& Hjörleifsson, S. (2007) Geneticization and bioethics: advancing debate and research. Medicine, health care, and philosophy, 10, 417-431.

Árnason, V., Nordal, S. \& Ástgeirsdóttir, K. (2010) Siðferði og starfshœettir í tengslum við fall íslensku bankanna 2008 [Morality and work practice in relation to the fall of the Icelandic banks 2008]. Report of the Special Investigation Commission, Vol. 8. Reykjavik: Icelandic parliament.

Berlin, I. (1969) Two Concepts of Liberty. In Four Essays on Liberty. Oxford: Oxford University Press.

Clifford, W. (1961) The ethics of belief? In Religion from Tolstoy to Camus, ed. W. Kaufmann, pp. 201-220. Harper Torchbooks.

Foot, P. (1978) Virtues and Vices. University of California Press.

Grímsson, Ó.R. (2003) Keynote Address by the President of Iceland at «A Country of Progress - A World of Opportunities», Investments Conference, Copenhagen October 23, 2003. Available at www.forseti.is/ media/files/ 03.10.23.Kaupm.hofn.business.pdf

Gudmundsson, M. (2009) Hin alpjóðlega fjármálakreppa [The International Financial crisis]. Skírnir 183 (Spring), 5-38.

Hellman, T., Murdock, K. \& Stiglitz, J. (1997) Financial Restraint. Towards a New Paradigm. In The Role of Government in East Asian Economic Development. Comparative Institutional Analysis, ed. M. Aoki, H-K. Kim \& M. Okuno-Fujiwara, pp. 163-207. Oxford: Clarendon Press.

Jonas, H. (1984) The Imperative of responsibility. Chicago: The University of Chicago Press.

Klein, N. (2007) The Shock doctrine. The Rise of disaster capitalism. Penguin books.

Kristinsson, G.H. (2007) Íslenska stjórnkerfið [The Icelandic political system] (2nd. ed.). Reykjavik: University of Iceland Press.

Lemieux, C.M. (1999) Conglomerates, Connected Lending and Prudential Standards. Lessons Learned. Emerging Issues Series. Supervision and Regulation Department. Federal Reserve Bank of Chicago.

Magnússon, G. (2008) Nýja Ísland. Listin að týna sjálfum sér. Reykjavík: JPV.

Mishkin, F.S. \& Herbertsson, T.T. (2008) Financial Stability in Iceland. Reykjavik: Icelandic Chamber of Commerce.

Nordal, S. (2009) Self-interest, deregulation and trust. Etikk i praksis. Nordic Journal of Applied Ethics, 3 (2), pp. 52-63.

Ólafsson, S. (2008) Iceland's Economic Miracle: From Prosperity to Libertarianism and Financial Collapse. Stjórnmál og stjórnsýsla, (Autumn), pp. 231-256.

Sen, A. (2000) Development as Freedom. New York: Anchor Books.

Sigurdsson, B.G. (2007) Útrás og árangur bankanna. [Breakout and success of the banks]. Viðskiptablaðið, 21. desember 2007. 
Skarstein, R. (2008) Økonomi på en annen måte. Makt og penger fra europeisk føydalisme til globalisert kapitalisme. Oslo: Abstrakt forlag.

Weitzner, D. \& Darroch, J. (2009) Why moral failures precede financial crises. Critical perspectives on international business, Special issue: Reflections on a global financial crisis, 5 (1-2), pp. 613.

Young, I.M. (2006) Responsibility and Global Justice: A Social Connection Model. Social Philosophy and Policy, 23, pp. 102-130. 